\title{
INFLUENCE OF PERSONALITY CHARACTERISTICS ON ETHNIC MORALITY
}

\author{
Bukunmi O. Adewumi [BSc]., Ifeloluwa O. Solomon [BSc., MSc.] \\ Department of Psychology, Faculty of the Social Sciences, Ekiti State University, Nigeria. \\ adewumibukunmi@gmail.com, lovesolomon@ rocketmail.com
}

\begin{abstract}
This study aimed at investigating the influence of personality characteristics on ethic morality. Evidently, two hundred research participants were included for this study from among the Ekiti State University Undergraduate Students. Two research instruments that were used in the course of this study include; Big five personality trait questionnaire developed by John (1991) a measure personality and Ethic Moral Self-Inventory developed by Olukoya (1998). Four hypotheses were tested, Regression, Analysis of Variance and Independent t-test statistical test were used to analyze the hypotheses respectively. Result revealed that there was a significant influence of personality characteristics on ethic morality $(F(5,192)$ $=8.18 \mathrm{P}<.05)$. It was also revealed from the study that age significantly influenced ethic morality $(F(3,194)=9.592 P<.05)$. Result also revealed that, marital status influenced ethic morality $(t(189)=3.027$ $P<.05)$. Finally, family structure has a
\end{abstract}

significant influence on ethic morality. $(t(189)=-2.60 \quad P<.05)$. Findings are discussed according to the literatures and it was recommended that parent and guardians should develop a policy in enacting and promoting moral teachings among their children. Further studies are recommended on this topic.

\section{INTRODUCTION}

Put in its simplistic term, morality is the difference between right and wrong, and those who exhibit either of this two attributes do in fact, demonstrate a moral behaviour. Generally, as there are many that modulate human behaviours, there are many factors that modulate moral behaviour of every individual. The study of personality is probably more difficult and contentious than other fields of psychology. Various people defined personality according to their perceptions of the term. Personality is often considered as whatever makes an individual different or unique from another individual. According to Ryckman (2009), personality 
can be defined as a dynamic and organized set of characteristics possessed by a person that uniquely influences his or her cognitions, motivations and behaviours in various situations.

Personality has become an individual constitution (both biological and psychological) which makes behaviour unique and consistent overtime. Herein, the investigation of personality traits and ethnic would necessitate the study of how each of the five personality traits

(Openness to experience,

Conscientiousness, Extraversion, Agreeableness, and Neuroticism) as defined in the Big Five Personality theory relates to life satisfaction.

\section{Statement of Problem}

In our society, children are sometimes exposed at an early age to all sort of dangers arising from malnutrition, diseases and various temptation of surviving due to the absence of one or both of their parents. Childs' life in broken homes is observed to be associated with emotional stress that can impair intellectual development, thereby, giving way for such children to grow up without being trained properly. Depending upon circumstances, children may be faced with feelings of abandonment, rejection, selfblame, entitlement or many other puzzling reactions. Despite good intentions, it's easy for parents to compound the problem through attempts to make their child feel better or to get them to accept the realities of life.

This can set the stage for later problems in a child's development, fears of attaching to the opposite sex, ingrained attitudes about what is "owned to them, or pent up emotions that compromise the quality of life, are examples of how parent absence can leave lasting psychological scars. However, the absence of one or both parents deprives young children of the stable love, care, security and total support they have been accustomed to and tend to make children different in the eyes of the peer group. If children are asked where the missing parent is or why they have a new parent to replace the missing parent, they become embarrassed and ashamed. They may also feel guilty and unwanted by the society such stressful situation leads to psychological, emotional and intellectual imbalance in growing children. This subsequently results in bad habit like smoking, immorality, quieting from school or poor academic achievement as education require critical thinking, relax mind and proper family support to be able perform to expectation in the school. Hence, it becomes expedient to understand 
the personality characteristics of individual on morality.

\section{Purpose of the study}

The main purpose of the study is to investigate the influence of personality characteristics on ethic morality. Other purposes of this study include:

- To determine whether age will influence ethic morality

- To investigate whether marital status will influence ethic morality

- To investigate whether family structure will influence ethic morality

- There will be a significant influence of personality characteristics on Ethic morality.

\section{Relevance of the study}

The main importance of this study is to understand the personality characteristics of individual and its influence on morality. The result obtained would be tremendous help to children in developing a good moral and personality. It would serve as a framework in making logical conclusion which would be a sort of guide to parent and children in single parent homes.

This study is done also for the enhancement of knowledge and the outcome or result would also have greater relevance to the school and society at large. It will serve as reference materials for other researcher

\section{Hypotheses}

1. There will be a significant influence of personality characteristics on Ethic morality.

2. There will be a significant influence of age on ethnic morality.

3. There will be a significant influence of marital status on ethnic morality.

4. There will be a significance influence of family structure on ethnic morality.

\section{RESEARCH METHODS}

The method used in this research entails the research design and the procedure that was used to conduct the study. The procedure was discussed under the research design, area of the study, population of the study, sample and sampling technique, instrument for data collection, validation of the instrument, reliability of the instrument, method of data collection and method of data analysis.

\section{- Survey Research Design}

The design used for this study was a survey research design. Questionnaires 
were designed for gathering information from 200 participants.

\section{- Research participants}

A random sample of 200 respondents was selected and it consisted of one hundred and twenty five (100) males and one hundred and twenty five (100) females; the age of the respondents range from 18-27 years.

\section{- Area of study}

For the purpose of this study, which is the effect of personality characteristics on the morality? I choose my study area to be Ekiti State University Ado-Ekiti, in which this research is conducted among them.

\section{- Sampling method}

The sampling method adopted for this study is simple random sampling technique. This technique is employed because the entire population of interest may not be totally accessible, it is therefore necessary to select a represent group from the population such that those selected will adequately represent those that were not selected.

\section{- Research Instruments}

The solidly made use of three different questionnaires to measure the variable under study which were Alabama parenting questionnaire for children, Ethical-Moral self-Inventory, Big five personality inventory.

\section{- Alabama Parenting}

Questionnaire (APQ)

The APQ measures five dimensions of parenting that are relevant to the etiology and treatment of child externalizing problems: (1) positive involvement with children, (2) supervision and monitoring, (3) use of positive discipline techniques,(4) consistency in the use of such discipline and (5) use of corporal punishment. It was Developed by Frick, P. J. (1991).APQ is a 48- item scale with (5) five points rating scale ranging from (1.)Never, (2) Almost never, (3) Sometimes, (4) Often (5)Always

\section{Psychometric properties}

Information on reliability and validity are provided below. If information on a particular psychometric was not found, it is indicated as "no information provided." It should be noted that this is not necessarily an indication of a lack of reliability or validity within a particular scale/instrument, but rather a lack of rigorous testing, for various reasons, by the developers or other researchers. 


\section{Reliability:}

A correlation of at least .80 is suggested for at least one type of reliability as evidence; however, standards range from .5 to .9 depending on the intended use and context for the instrument. Internal Consistency: The average reliability across the APQ scales is .68.Inter-rater reliability: No information provided Test-Retest: No information provided

\section{Validity:}

The extent to which a measure captures what it is intended to measure. Content/Face Validity: No information provided Criterion Validity: The APQ has good psychometric properties including criterion validity in differentiating clinical and nonclinical groups (Fraser, 2003; Frick, Christian, \& Wooton, 1999; Shelton et al., 1996). Frick et al. (1999) reported a mean $\mathrm{r} 2$ across its five scales of 0.24 for predicting child symptoms of ODD and CD. Independent investigations have also shown the APQ to be an informative assessment tool. Construct Validity: No information provided

\section{Scoring for Child Form:}

The items on the child form are categorized into five subscales that are reflective of the parent subscales:
-Involvement: 1, 4, 7, 9, 11, 14, 15, 20, 23, 26 (there are two parts to each of these questions - one for mother involvement and one for father involvement).

- Positive Parenting: 2, 5, 13, 16, 18, 27

- Poor Monitoring/Supervision: 6, 10, 17, $19,21,24,28,29,30,32$

- Inconsistent Discipline: 3, 8, 12, 22, 25, 31

\section{-Corporal Punishment: 33, 35, 39}

-No reverse coding necessary.

-Sum all items in the scale to obtain a total scale score (you may subtract this score by the number of items in the subscale so that the score range begins at zero).

- Other Discipline Practices is not a scale, but provides information on an item by item basis. Numbers for these items are: $34,36,37,39,40,41,42$

\section{- Ethical- moral self inventory}

The 28-item inventory is the moralethical self scale which is one of the five scales in Tennessee self concept scale (Tscs)(Fiths, 1965) EMSI consists of the 18 moral- ethical self scale items and the 10 self - criticism items of the Tscs. EMSI has been developed into an independent inventory owning to the increasing significance. Its also has five points rating scale ranging from ( ) completely false,( 
)mostly false, ( ) partly false\& true, ( ) mostly true, ( ) completely true.

Morality has been assuming in clinical and social research in Nigeria, morality in the context of this scale, is conceptualized as the tendency by an individual to adopt the principles of fairness, equity integrity, justice in guiding his or her behavior in social interactions. The ethic- morality concept therefore covers more ground than adopting the principle of right and wrong to evaluate social situations. The self criticism scale is the validity scale of the TSCS.

\section{Scoring}

There is direct scoring and reverse scoring of the items.

(a) direct scoring: add together the values of the numbers in the relevant.

(b) Reverse scoring: change the values of the number from 1,2,3,4,5 to $5,4,3,2,1$ respectively and add together the reversed values of the number shaded in the relevant items.

(c) EMSI scale

-Direct

score

items-

$1,2,6,11,12,16,21,22,25$.

-Reverse score items$3,7,8,13,17,18,23,27$.
(D) Self criticism scale (SCS).

-Direct score items: $4,5,9,10,14,15,19,20$.

(E) Final score

-EMSI scale: add together the result of the direct score and the reverse score items as shaded in the final EMSI score.

- SCS: add together the values of items for the scale.

\section{Psychometric properties}

Fitts (1965) provided the original samples, while Ezeilo $(1982 ; 1985)$ and Olukoya (1998) provided the properties for Nigeria samples.

\section{- Norms}

The norms reported here are the mean, scores obtained by people in the general population.

\section{Group. EMSI.}

Teenagers. $\quad 61.90$

Adolescents. 63.70

\section{Reliability.}

The test-retest reliability coefficients obtained for the full TSCS test which EMSI is a subscale are 92 by fitts (1965) and 7.4 by Ezeilo (1982). 
Validity

Olukoya (1998) obtained a current validity coefficient of 0.15 by correlating EMSI with index of self-esteem (Hudson, 1982).

\section{Interpretation}

The Nigeria norms or mean score are the basis for interpreting the scores of clients. Those with score higher than the norms indicate high ethic morality and personality characteristics.

\section{- The Big Five Personality Test}

This is a personality test that will help you understand why you act the way that you do and how your personality is structured. It is a 10 item inventory which is a shorter version of the lengthy BFI (John, Donahue, \& Kentle, 1991) which consist of 44 items, with five point rating scale ranging from (1)disagree, ( 2)slightly disagree, (3 )neutral, ( 4) slightly agree, ( 5) agree. Big five personality test further divided into personality facets namely:

(1) Extroversion (E) is the personality trait of seeking fulfillment from sources outside the self or in community. High scorers tend to be very social while low scorers prefer to work on their projects alone.
(2) Agreeableness (A) reflects much individuals adjust their behavior to suit others. High scorers are typically polite and like people. Low scorers tend to 'tell it like it is'.

(3) Conscientiousness (C) is the personality trait of being honest and hardworking. High scorers tend to follow rules and prefer clean homes. Low scorers may be messy and cheat others.

(4) Neuroticism $(N)$ is the personality trait of being emotional.

(5) Openness to experience $(\mathrm{O})$ is the personality trait of seeking new experience and intellectual pursuits. High scores may day dream a lot.low scores may be very down to earth.

\section{Psychometric properties}

\section{Reliability}

The authors obtained test- retest reliability among two samples of different cultures, the coefficient are as follows: .72 in US sample, .78 in German sample, and .75 overall, suggesting that the BFI -10 scales achieved respectable levels of stability over 6-8weeks in both cultures.

\section{Validity}

The test- retest correlations reported for the BFI-10 scale are thus: extraversion .83 , agreeableness .68, conscientiousness 
.77 , openness to experience .72 , and neuroticism .74 .

\section{Scoring}

Some of the items are reverse when scoring. They are items 1,3,4,5, and 7 . Extraversion was assessed with items 1R, 6. ( $\mathrm{R}$ denotes reversed section). Agreeableness: 2, 7R. Conscientiousness: $3 R, 8$. Openness to experience: $5 R, 10$ and Neuroticism: 4R, 9.

\section{Interpretation}

The scoring procedure of this scale indicated that the higher the score of an individual on a particular factor, the more significant that individual is on that factor.

\section{Procedure}

At the beginning of the administration of the instruments a rapport was established by the researcher with respondents. The questionnaires were distributed to a randomly sampled 250 children brought up by a single parent populace to inquire how they perceived their own morality and personality characteristics. Those who could not understand some of the items of the questionnaire were helped through vivid explanation.

\section{Statistical Analysis}

After administration and collection, the data were subjected to statistical analysis. Regression was used to test hypothesis one and two. Pearson product moment correlation was used to test the hypothesis three.

\section{RESULTS}

This is a summary to give a description on the analysis in the study

Table 1: Regression summary table showing a significant influence of personality characteristics on ethic morality

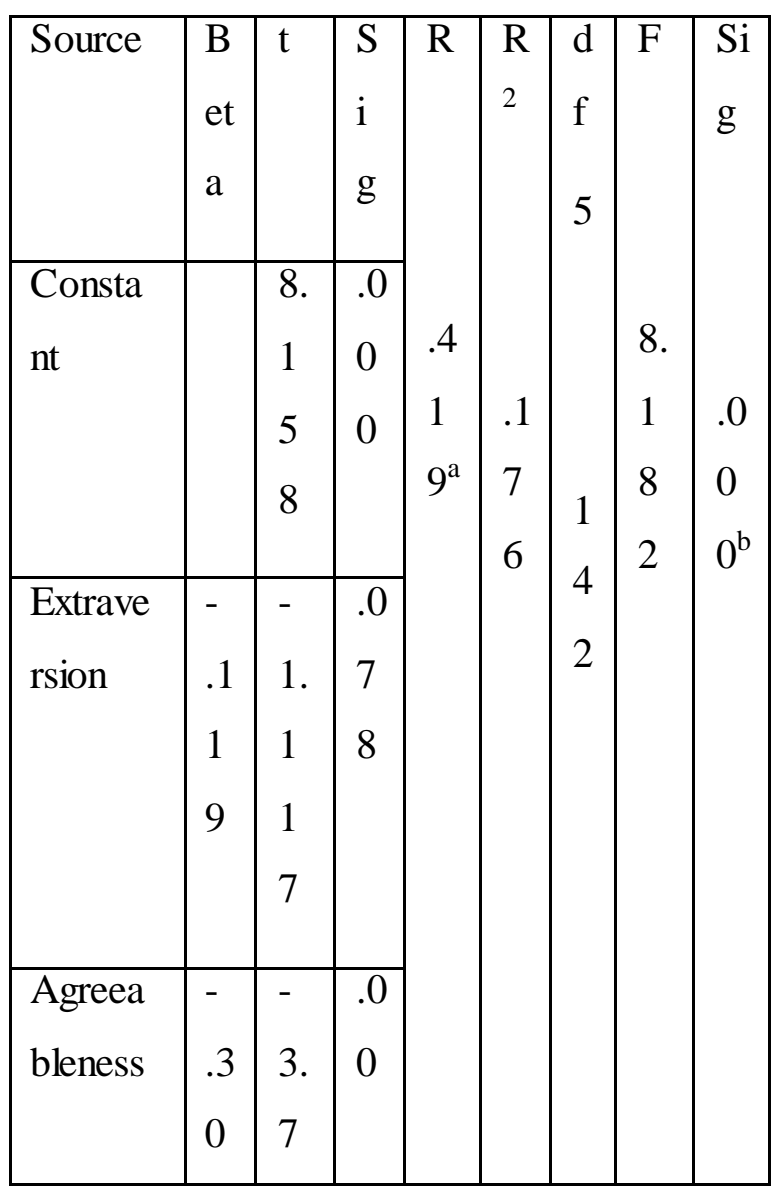




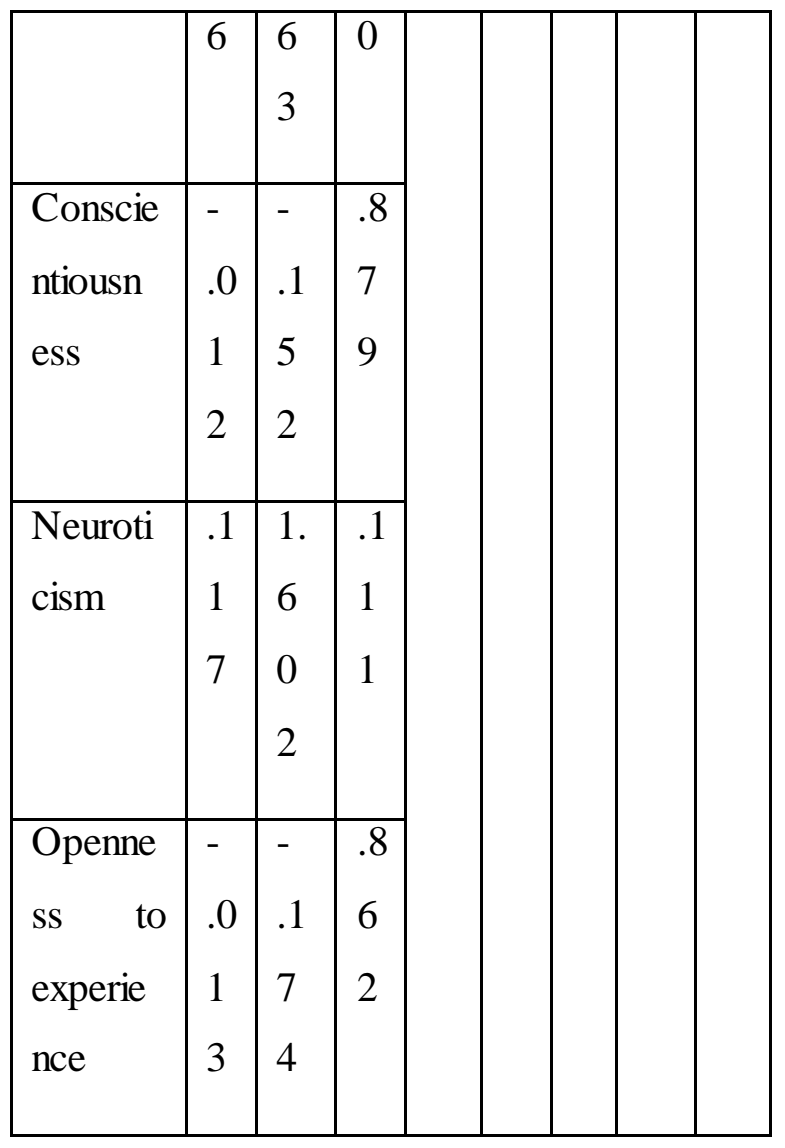

The table shows that age has a significant influence on ethic morality $(\mathrm{F}(3,194)=$ $9.592 \mathrm{P}<.05)$

Table 3: Independent t-test summary table showing the influence of marital status on ethic morality

Group Statistics

\begin{tabular}{|c|c|c|c|c|c|c|c|c|}
\hline & $\begin{array}{l}\text { Ma } \\
\text { rita } \\
1 \\
\text { stat } \\
\text { us }\end{array}$ & $\mathrm{N}$ & $\begin{array}{l}\mathrm{Me} \\
\text { an }\end{array}$ & $\begin{array}{l}\text { Std. } \\
\text { Devi } \\
\text { ation }\end{array}$ & $\begin{array}{l}\text { Std. } \\
\text { Err } \\
\text { or } \\
\text { Me } \\
\text { an }\end{array}$ & $\begin{array}{l}\mathrm{D} \\
\mathrm{f}\end{array}$ & $t$ & $\begin{array}{l}\mathrm{S} \\
\mathrm{i} \\
\mathrm{g}\end{array}$ \\
\hline $\begin{array}{l}\text { Ethi } \\
\text { c } \\
\text { Mor } \\
\text { alit } \\
\text { y }\end{array}$ & $\begin{array}{l}\text { Ma } \\
\text { rrie } \\
\text { d }\end{array}$ & 3 & $\begin{array}{l}57 . \\
109 \\
1 \\
52 . \\
125 \\
0\end{array}$ & $\begin{array}{l}10.7 \\
0025\end{array}$ & $\begin{array}{l}1.2 \\
452 \\
4\end{array}$ & $\begin{array}{l}1 \\
8 \\
9\end{array}$ & $\begin{array}{l}3 . \\
02 \\
7\end{array}$ & $\begin{array}{l}.0 \\
0 \\
3\end{array}$ \\
\hline
\end{tabular}
morality

ANOVA

Ethic morality

\begin{tabular}{|l|l|l|l|l|l|}
\hline & $\begin{array}{l}\text { Sum } \\
\text { Squares }\end{array}$ & of Df & Mean Square & F & Sig. \\
\hline Between Groups & 2819.281 & 3 & 939.760 & 9.592 & .000 \\
Within Groups & 19007.310 & 194 & 97.976 & & \\
Total & 21826.591 & 197 & & & \\
\hline
\end{tabular}

The table shows that marital status influences ethic morality $(\mathrm{t}(189)=3.027$ 
Table 4: Independent t-

test summary table

showing the influence of

family structure on ethic

morality

Group Statistics

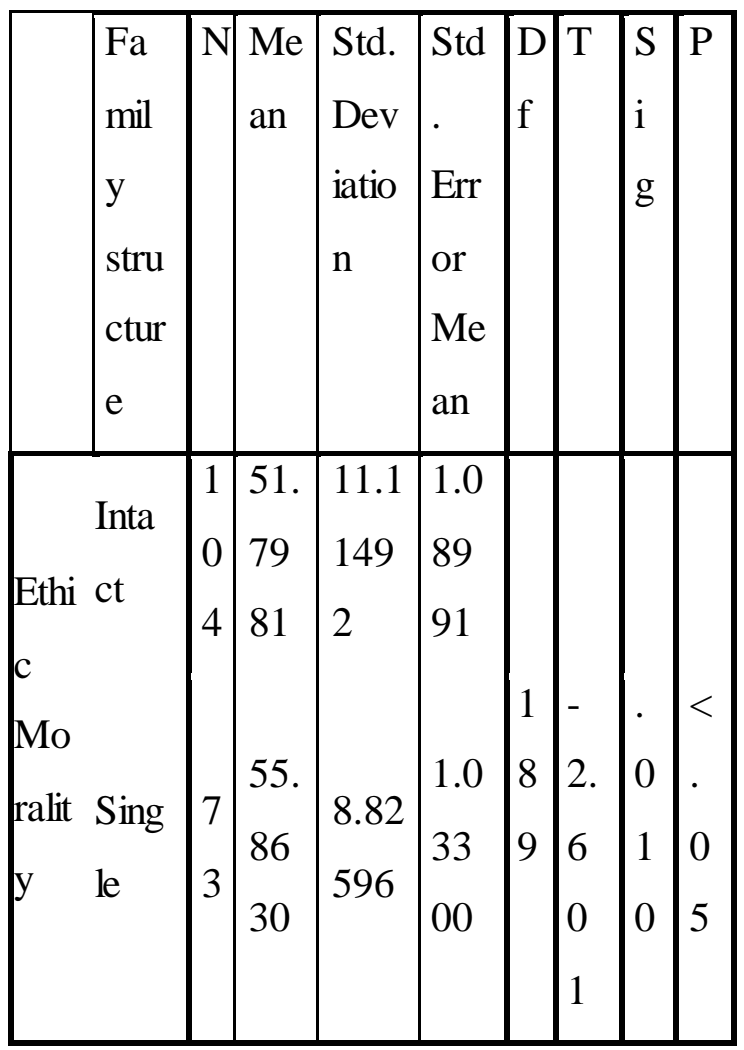

The table shows that family structure has a significant influence on ethic morality. ( $\mathrm{t}$ $(189)=-2.601 \quad \mathrm{P}<.05)$

\section{DISCUSSION, CONCLUSION AND RECOMMENDATION}

\section{DISCUSSION}

Hypothesis one states that personality characteristics will influence ethic morality. It was observed from the study that personality has an influence on ethic morality. $(\mathrm{F}(5,192)=8.18 \quad \mathrm{P}<.05)$.

This result is supported by Santrock (2004) which explains the development of morality which is significant to the personal characteristics. He posited that introvert tends to be more moral as result of upbringing and their socialization process. Individual differences play a major role in influencing ethic morality and this could be attributed to individual ability and actualization during the childhood and stages of development.

Hypothesis two states that age will influence ethic morality and it was observed from the study that age has a significant influence on ethic morality $(\mathrm{F}(3,194)=9.592 \mathrm{P}<.05)$. This result is supported by Kembe (2005), he posited that age was an important tool in influencing ethic morality. Young individual tends to be less moral than older individual; this may be as a result of experience and exposition towards life.

Hypothesis three states that there is a significant influence of marital status on ethic morality and it was observed from the study that marital status influences ethic morality $(\mathrm{t} \quad(189)=3.027 \quad \mathrm{P}<.05)$. This area of research needs more exploration, as there is currently spurious data to justify this hypothesis. It is important to understand that married individual tends to be more conscious of 
what they do and things they do which may affect their marital rejuvenation in the society. Married individual tends to be more responsible and committed in other not to violate the order society placed on them.

Hypothesis four states that family structure will have a significant influence on ethic morality. It is glaring from this research that family structure has a significant influence on ethic morality. $(\mathrm{t}(189)=-2.60 \quad \mathrm{P}<.05)$. This result was supported by Kembe (2005) in his research carried out on influence of family background on patterns of child misbehavior. Result shows that behavior vices such as lateness to school, examination malpractices, and use of drugs, illicit sexual relationship and improper dressing were identified as common patterns of child misbehavior. Family is the sole area of socialization and development starts from home and this thus has a major influence on ethic morality of children.

\section{CONCLUSION}

Having discussed from the result, it is important to conclude that personality characteristics influences ethic morality. Also, it is concluded that age has a significant influence on ethic morality. Also, there is a significant influence of marital status on ethic morality. We can also conclude that family structure influences ethic morality.

\section{RECOMMENDATIONS}

From the conclusion, it is highly recommended that parent and guardians should develop a policy in enacting and promoting moral teachings among their children. Also it is recommended that nongovernmental bodies like religion should improve their standard in promoting moral ethics among adolescent.

\section{REFERENCES}

Ezeilo, B.N. (1982). Cross cultural utility of the Tennessee Self-Concept Scale. Psychological Reports, 51, 897-898.

Fitts, W. H. (1965). Manual for the Tennessee Self-Concept Scale. Nashville: Counsellor Recordings \& Tests.

Frick, P.J., Christian, R.C. \& Wootton, J.M. (1999). Age trends in the association between parenting practices and conduct problems. Behavior Modification, 23, 106-128.

Hudson, W.W. (1982). Index of self esteem. The Clinical Measurement Package: A Field Manual. Chicago: Dorsey Press.

John, O. P., Donahue, E. M., \& Kentle, R. L. (1991). The Big Five Inventory-Versions 4a and 54. Berkeley, CA: University of California,Berkeley, Institute of Personality and Social Research. 
Kembe, E.M. (2005). Influence of Family Background on Patterns of Child Misbehaviour in Makurdi Metropolis. Journal of Home Economics Research. $6(1), 166-170$.

Maddi, S. (1989). Personality theories; a comparative analysis Chicago: Dorsey Press.

Olukoya, E.I. (1998). The effect of age and gender differences on morality and selfesteem of Nigeria adolescents. Unpublished M.Sc Research Project, department of Psychology, University of Lagos.

Ryckman, J. J. (2009) Educating Exceptional Children, 6th Edition, Boston, Houghton Mifflin .Co. Konting, M. M., Kamaruddin K, Nor Azirawani Man, Azura Adam, Siti Norziah Abdullah. (2007). Penaksiran

Ryckman, R. M. (2009). Theories of Personality. 9th ed. Wadsworth Publication Company.

Shelton, K.K., Frick, P.J., \& Wootton, J. (1996). The assessment of parenting practices in families of elementary school-aged children. Journal of Clinical Child Psychology, 25, 317-327.

Santrock, J.W. (2004). Life-span Development $9^{\text {th }}$. McGraw-Hill Companies, inc. New York. 